\title{
Surface Energy Balance Affects Gas Exchange and Growth of Two Irrigated Landscape Tree Species in an Arid Climate
}

\author{
Thayne Montague, ${ }^{1}$ Roger Kjelgren, ${ }^{2}$ and Larry Rupp ${ }^{3}$ \\ Department of Plants, Soils, and Biometeorology, Utah State University, Logan, UT 84322-4820
}

AdDitional INDEX wORDs. gas exchange, crop coefficient, urban surface, Norway maple, Acer platanoides 'Emerald Queen', littleleaf linden, Tilia cordata 'Greenspire'

\begin{abstract}
Research was conducted to investigate how energy balance of bark mulch and turf surfaces influence gas exchange and growth of recently transplanted trees. On several occasions over a 3-year period, stomatal conductance and leaf temperature were measured throughout the day on 'Emerald Queen' Norway maple (Acer platanoides L.) and 'Greenspire' littleleaf linden (Tilia cordata Mill.) trees growing over each surface. Tree water loss was estimated using a general transport flux equation applied to the tree crown apportioned between sunlit and shade layers. Microclimate variables were measured over each surface with a permanent weather station. Tree growth data were collected at the end of each growing season. Soil heat flux data revealed that a greater portion of incoming radiation was prevented from entering the soil below mulch than below turf. Due to this insulating effect, and consequent lack of evaporative cooling, mulch surface temperature was greater, and emitted more longwave radiation, than turf. Leaves over mulch intercepted more longwave radiation, had greater leaf temperature, and greater leaf-to-air vapor pressure difference than leaves over turf. As a result, leaves over mulch had greater stomatal closure than leaves over turf. Estimated tree water loss varied between surface treatments and with climatic conditions. Trees over turf had greater shoot elongation and leaf area than trees over mulch. These data suggest that gas exchange and growth of recently transplanted trees in an arid climate may be reduced if planted over nonvegetative, urban surfaces.
\end{abstract}

Tree gas exchange is controlled largely by the response of the plant to the environment (Heilman et al., 1989). In urban areas, lack of vegetation, increased longwave radiation (Heilman et al., 1989), and increased combustion have created the effect of an urban heat island (Kim, 1992). Nonvegetative, urban surfaces lack evaporative cooling and, compared to vegetative surfaces, can be good conductors of energy (Kjelgren and Montague, 1998). Therefore, nonvegetative urban surfaces store more energy and have greater surface temperature $\left(T_{S}\right)$ than vegetative urban surfaces (Doll et al., 1985; Mastalerz and Oliver, 1974). Greater $T_{S}$ increase longwave radiation flux ( $\mathrm{L} \uparrow$ ) and sensible heat, which can increase air temperature $\left(\mathrm{T}_{\mathrm{A}}\right)$ and decrease relative humidity $(\mathrm{RH})$ in urban environments compared to rural areas (Kim, 1992; Landsberg, 1979).

Leaves of woody plants placed near nonvegetative surfaces intercept more sensible heat and $\mathrm{L} \uparrow$ than plants over a vegetative surface (Montague et al., 1998). Consequently, trees over nonvegetative surfaces may have greater leaf temperature (Kjelgren and Montague, 1998; Whitlow and Bassuk, 1988) and leaf-to-air vapor pressure difference (Kim, 1992; Whitlow and Bassuk, 1987) and lower stomatal conductance (Montague et al.,

Received for publication 9 Aug. 1999. Accepted for publication 18 Jan. 2000. This research was supported by the Utah Agricultural Experiment Station, Utah State University, Logan, UT 84322-4820. Approved as journal paper no. 7212. This paper represents a portion of a dissertation submitted by $\mathrm{T}$. Montague for the $\mathrm{PhD}$ in Plant Science at Utah State University. Mention of a trademark, proprietary product, or vendor does not constitute a guarantee or warranty of the product by Utah State University and does not imply its approval to the exclusion of other products or vendors that also may be suitable. The cost of publishing this paper was defrayed in part by the payment of page charges. Under postal regulations, this paper therefore must be hereby marked advertisement solely to indicate this fact.

${ }^{1}$ Former graduate student. Current address: Department of Plant and Soil Science, Texas Tech University, Lubbock, TX 79409-2122.

${ }^{2}$ Associate professor.

${ }^{3}$ Professor.
1998) than plants over vegetative surfaces. Depending on species and climate, woody landscape plants in urban environments may have increased (Potts and Herrington, 1982; Zajicek and Heilman, 1991) or decreased (Kjelgren and Clark, 1993; Kjelgren and Montague, 1998) water loss when compared to woody plants in nonurban environments. Lack of urban tree growth has also been attributed to reduced gas exchange levels caused by high leaf-toair vapor pressure differences (LVPD) found in urban locations (Kjelgren and Clark, 1992b, 1993). Additional factors that limit growth of trees in urban areas include poor soil (Graves et al., 1989), reduced incoming shortwave radiation (Kjelgren and Clark, 1992a), and pollution (Bassuk and Whitlow, 1987).

Water use of isolated trees has been estimated by several methods. However, little research has been conducted on the effect urban surfaces have on tree water loss. Indirect measurement of water loss from isolated trees has been done using energybalance models (Kjelgren and Montague, 1998; Landsberg and McMurtrie, 1984) with good agreement between measured (lysimeter) and calculated values. Standard flux equations such as those proposed by Choudhury and Monteith (1986) and Jones (1992) have few input variables and are adequately robust such that they may be used in many circumstances. Although energy-balance models and standard flux equations may precisely estimate water use of an isolated tree, each method has computational or practical limitations that limit usefulness.

In agriculture, crop coefficients $\left(\mathrm{K}_{\mathrm{C}}\right)$ parameterize water loss of a plant species as a function of reference evapotranspiration $\left(\mathrm{ET}_{\mathrm{O}}\right)$ and are a common method for estimating crop evapotranspiration $\left(\mathrm{E}_{\mathrm{C}}\right)$ requirements (Allen, 1993; Devitt et al., 1992). The dimensionless $\mathrm{K}_{\mathrm{C}}$ is computed as: $\mathrm{E}_{\mathrm{C}}=\left(\mathrm{K}_{\mathrm{C}}\right) \times\left(\mathrm{ET}_{\mathrm{O}}\right)$ where $\mathrm{ET}_{\mathrm{O}}$ is reference evapotranspiration calculated for a well watered, nonstressed, cool-season grass of uniform height (Allen, 1993) and both $\mathrm{E}_{\mathrm{C}}$ and $\mathrm{ET}_{\mathrm{O}}$ have units of depth of water evaporated for each unit of time. Crop coefficients for several orchard tree species are found in the literature and are generally based on unit 
of orchard ground area (Hoffman et al., 1982; Tan and Layne, 1981). However, little research has been conducted to find $K_{C}$ values for isolated landscape trees. Garbesi (1992) reports isolated trees had acceptable growth and appearance with a leaf area based $\mathrm{K}_{\mathrm{C}}$ value of 0.5 . Levitt et al. (1995) used lysimeters to estimate $\mathrm{K}_{\mathrm{C}}$ values for nonwater-stressed 'Colorado' Argentine mesquite (Prosopis alba Torr.) and 'Heritage'live oak (Quercus virginiana Mill.). They based their $\mathrm{K}_{\mathrm{C}}$ per unit leaf area and estimated $\mathrm{K}_{\mathrm{C}}$ for mesquite and live oak as 0.5 and 1.0, respectively.

There is a lack of information on how water loss of isolated trees in arid climates is influenced by nonvegetative urban surfaces. Past research on water loss of isolated trees has been conducted primarily in regions of high RH. In such regions, LVPD is generally lower than LVPD in arid regions and in urban environments. There is also little information on how isolated landscape trees respond to urban environments found in arid regions. Therefore, the purpose of this study was to investigate the energy balance of two landscape surfaces in an arid climate, determine how surface energy balance influences gas exchange and growth of two nonwater stressed ornamental tree species grown over each surface, and determine $\mathrm{K}_{\mathrm{C}}$ values for each species using a standard flux equation.

\section{Materials and Methods}

This research was conducted at the Utah State University research farm in Logan, Utah. In Spring 1995, we planted four 5cm caliper, field-grown, balled and burlaped, 'Emerald Queen' Norway maple (Acer platanoides) and four 'Greenspire' littleleaf linden (Tilia cordata) trees in a well-drained, Millville silt loam, coarse-silty, carbonatic, mesic, Typic Haploxeroll soil. At transplanting, mean overall and first branch height was 5.1 and $1.5 \mathrm{~m}$, respectively, for the maple trees, and 3.7 and $1.1 \mathrm{~m}$, respectively, for the linden trees. All trees conformed to American Association of Nurserymen Standards specifications (American Association of Nurserymen, 1996). To represent a nonvegetative, urban surface, an area $24 \times 17 \mathrm{~m}$ surrounding the trees was covered with $15 \mathrm{~cm}$ of coarse pine bark mulch. After planting, mulch was placed to the trunk of each tree. Trees were spaced $7 \mathrm{~m}$ apart and each tree was surrounded by a minimum of $6 \mathrm{~m}$ of mulch. An area $38 \times 10 \mathrm{~m}$ consisting of established Kentucky bluegrass (Poa pratensis L.) was used to represent a vegetative surface. This area was $9 \mathrm{~m}$ north of the mulched surface. In this area four trees of each species were planted in a design similar to the mulch surface. Trees were in full sun during the day. As in most urban landscapes, an assortment of different surfaces surrounded the study. An asphalt road and agricultural areas bordered the experimental area to the west, and agricultural areas surrounded the experiment on the north, south, and east. South of the turf area, bare soil extended to the mulched area. East of the turf area, additional turf extended for $38 \mathrm{~m}$. To reduce the effect that advected energy may have on individual tree energy balance, two rows of miscellaneous tree species were planted at the beginning of the experiment between the two surface treatments. These rows were $1.5 \mathrm{~m}$ apart with trees spaced $1 \mathrm{~m}$ apart within each row. At the end of the experiment, these trees were 2 to $4 \mathrm{~m}$ in height. Prevailing wind direction was from the southeast in the morning and from the northwest in the afternoon and evening (Utah Climate Center, 1997).

For the duration of the experiment, a circle of bare soil (radius $=0.5 \mathrm{~m}$ ) surrounded each tree in the turf treatment. During each growing season, experimental trees were irrigated with $0.095 \mathrm{~m}^{3}$ of water each week. Trees in the mulch treatment were irrigated twice a week using a drip emitter system supplying $0.019 \mathrm{~m}^{3} \cdot \mathrm{h}^{-1}$. Trees in the turf treatment were irrigated $1 \mathrm{~h}$ four times a week through a sprinkler system that applied $0.0035 \mathrm{~m}^{3} \cdot \mathrm{h}^{-1}$. The remaining irrigation was applied by hand. All trees were fertilized in mid-May 1996 and 1997 with $0.019 \mathrm{~m}^{3}$ of a $300 \mathrm{mg} \cdot \mathrm{L}^{-1}$ solution of 20N-4.4P-16.4K (Peter's Professional; Scotts Sierra Horticultural Products Co., Columbus, Ohio). Trees were not pruned.

An automated weather station placed over each surface was used to monitor surface energy balance and microclimate. Incoming shortwave radiation ( $\mathrm{S} \downarrow$ ) was measured with a pyranometer (model LI-200SA; LI-COR Inc., Lincoln, Nebr.). Soil heat flux $\left(\mathrm{S}_{\mathrm{F}}\right)$ and soil temperature $\left(\mathrm{T}_{\mathrm{O}}\right)$ were measured with a heat flow transducer (Radiation-Energy Balance Systems, Inc., Seattle, Wash.) and a 0.4-mm-diameter copper-constantan thermocouple (Omega Engineering Inc., Stamford, Conn.), respectively. Soil heat flux and $\mathrm{T}_{\mathrm{O}}$ sensors were placed $1 \mathrm{~cm}$ below the soil surface for mulch (16 cm below the top of the mulch surface) and in the root zone below the thatch layer for turf ( $14 \mathrm{~cm}$ below the top of the turf surface). At the time of installation, soil surrounding each sensor was saturated with water and allowed to drain to field capacity. Surface temperature was measured with an infrared temperature transducer (model 3000A; Everest InterScience Inc., Fullerton, Calif.) placed $0.5 \mathrm{~m}$ above each surface at $45^{\circ}$. Thermal conductivity of each surface was estimated as $\mathrm{K}=\left(\mathrm{S}_{\mathrm{F}}\right) /\left(\mathrm{T}_{\mathrm{S}}-\mathrm{T}_{\mathrm{O}}\right)$ / (D), where $\mathrm{K}$ is thermal conductivity $\left(\mathrm{W} \cdot \mathrm{m}^{-1} \cdot \mathrm{C}^{-1}\right)$ and $\mathrm{D}$ is depth below each surface at which $\mathrm{T}_{\mathrm{O}}$ and $\mathrm{S}_{\mathrm{F}}$ were measured (M.M. Caldwell, personal communication). Air temperature and RH were measured with a combination temperature and humidity probe (model CR500; Campbell Scientific Inc., Logan, Utah), and wind speed $(\mathrm{u})$ was recorded with a 3-cup anemometer (model 041A; Met One, Inc., Grants Pass, Ore.). All meteorological variables were measured $2 \mathrm{~m}$ above each surface. Sensors were scanned every $10 \mathrm{~s}$ and averages were recorded every $30 \mathrm{~min}$ with a data logger (model CR10x; Campbell Scientific).

During each growing season weekly predawn leaf water potential $\left(\psi_{\mathrm{L}}\right)$ was measured at $0600 \mathrm{HR}$ (Mountain Standard Time) on two leaves from each tree. Leaves were excised before dawn, sealed immediately in a plastic bag, and placed in a cooler (Karlic and Richter, 1979). Water potential was measured within $0.5 \mathrm{~h}$ of excision with a pressure chamber (model 3005; Soilmoisture Equipment Corp., Santa Barbara, Calif.). In conjunction with measuring $\psi_{\mathrm{L}}$ (Turner, 1991), tree gas exchange was measured on several occasions during 1995, 1996, and 1997. Morning-to-evening stomatal conductance $\left(g_{s}\right)$ and $\mathrm{T}_{\mathrm{L}}$ were measured 13 July, 1 Aug., and 13 Sept. 1995; 26 July, 29 Aug., and 4 Sept. 1996; and 26 Aug. and 8 Sept. 1997 with a steady-state porometer (model 1600; LI-COR) and a hand-held infrared thermometer (model 210ALCS; Everest InterScience, Inc.), respectively. Measurements began near $0800 \mathrm{HR}$ each study day. Four sunlit and two shade leaves on each tree were measured. Single trees from each surface treatment and species were grouped together to form a replicate. Measurements began on the first replicate species group in mulch and then continued on the first replicate species group in turf. This cycle was repeated until trees in all replicates were measured. Following measurement of the final replicate, the cycle was repeated after a 1-h break. Data collection ceased $\approx 1900$ HR. Throughout each study day, leaves on every tree were measured seven or eight times.

Midday (1300 and $1500 \mathrm{HR}$ ) full sun photosynthesis $\left(P_{n}\right)$ was measured on several occasions in 1995 (3, 16, and 29 Aug.) and 
$1996(9,12$, and 16 Aug.) with a portable infrared gas analyzer (model 6200; LI-COR) in closed mode (Mitchell, 1992). Three sunlit leaves were measured on each tree and three observations were taken on each leaf. Data collection began on the first replicate in mulch and continued in a similar manner as described above until each tree had been measured once.

At the end of each growing season, shoot elongation was measured on 10 randomly selected shoots on each tree and was based upon growth from bud scales to the terminal bud. Trunk diameter was measured with a digital caliper $30 \mathrm{~cm}$ above soil level before budbreak in early spring and again in the late fall. Before leaf drop, all leaves were removed from each tree. A subsample of 20 leaves was randomly selected from the total leaf sample of each tree and subsample leaf area was measured with a leaf area meter (model CI-203 with CI-203A attachment; CID, Inc., Vancouver, Wash.). To obtain total foliage dry weight (DW) for each tree, all leaves were dried at $60^{\circ} \mathrm{C}$ for 1 week. Subsample leaf areas to DW ratios were multiplied by the DW of the total foliage to estimate total leaf area for each tree $\left(A_{T}\right)$. Area under the crown dripline $\left(A_{D}\right)$ was calculated for each tree from the radius of the tree trunk to the tip of the longest branch measured in four cardinal directions. Leaf area index (LAI) for each tree was calculated by dividing $\mathrm{A}_{T}$ by $\mathrm{A}_{\mathrm{D}}$ (Peper and McPherson, 1998).

A general transport flux equation based on that presented by Choudhury and Monteith (1986) was used to determine tree water loss. Each tree canopy was divided into sunlit and shade layers (Denmead, 1984). Transpiration for each layer was calculated as

$\left.\mathrm{E}=(\mathrm{LVPD}) \times\left(g_{s}\right) \times\left[\left(\rho \times \mathrm{C}_{\mathrm{P}}\right) / \gamma \times \lambda\right)\right]$

where $\mathrm{E}$ is transpiration rate $\left(\mathrm{kg} \cdot \mathrm{m}^{-2} \cdot \mathrm{s}^{-1}\right)$; LVPD is leaf-to-air vapor pressure difference $(\mathrm{kPa})$ (calculated using saturated vapor pressure at leaf temperature and ambient vapor pressure (Jones, $1992)) ; g_{s}$ is stomatal conductance $\left(\mathrm{m} \cdot \mathrm{s}^{-1}\right) ; \rho$ is the density of air $\left(\mathrm{kg} \cdot \mathrm{m}^{-3}\right) ; \mathrm{C}_{\mathrm{P}}$ is the specific heat capacity of air at constant pressure $\left(\mathrm{J} \cdot \mathrm{kg}^{-1} \cdot \mathrm{C}^{-1}\right)$; $\gamma$ is the psychrometric constant $\left(\mathrm{kPa} \cdot \mathrm{C}^{-1}\right)$; and $\lambda$ is the latent heat of vaporization $\left(\mathrm{J} \cdot \mathrm{kg}^{-1}\right)$. Each layer had LVPD, $g_{s}$, TL, and LAI appropriate to fully sunlit or shade leaves. Sunlit leaf area index $\left(\mathrm{LAI}_{\mathrm{SUN}}\right)$ for each tree was calculated as a fraction of LAI (Jones, 1992) such that $\mathrm{LAI}_{\mathrm{SUN}}=\left[\left(1-\mathrm{e}^{(-\kappa) \times(\mathrm{LAI})}\right) /(\kappa)\right]$ where $\kappa$ is the canopy extinction coefficient to light and is based upon leaf orientation and solar elevation (Jones, 1992; Sampson and Smith, 1993). Shade leaf area index $\left(\mathrm{LAI}_{\mathrm{SHADE}}\right)$ was calculated as $\mathrm{LAI}_{\mathrm{SHADE}}$ $=\mathrm{LAI}-\mathrm{LAI}_{\mathrm{SUN}}$. Tree transpiration for each measuring cycle was determined by calculating the total time for each cycle, then using Eq. [1] with $g_{s}$ and TL measured for each leaf and appropriate 0.5$\mathrm{h}$ meteorological data. Transpiration rates between cycles were estimated by dividing the time between cycles in half and adding one-half of the additional time to the previous and subsequent cycle. Total tree transpiration $\left(\mathrm{E}_{\mathrm{TOTAL}}\right)$ for each cycle was then calculated in depth units $(\mathrm{mm})\left(\mathrm{kg}\right.$ transpiration $/ \mathrm{m}^{2}$ leaf area) as the fractional contribution of the sunlit and shade layers such that $\mathrm{E}_{\text {TOTAL }}=\left[\mathrm{E}_{\mathrm{SUN}} \times\left(\mathrm{LAI}_{\mathrm{SUN}} / \mathrm{LAI}_{\mathrm{TOTAL}}\right)\right]+\left[\mathrm{E}_{\mathrm{SHADE}} \times\left(\mathrm{LAI}_{\mathrm{SHADE}} /\right.\right.$ $\left.\mathrm{LAI}_{\text {TOTAL }}\right)$ ] where $\mathrm{E}_{\mathrm{SUN}}$ and $\mathrm{E}_{\mathrm{SHADE}}$ are transpiration rates $(\mathrm{mm})$ for sunlit and shade canopy layers. Daily estimated water loss was calculated as the sum of all cycles for each tree.

Morning-to-evening experiments on days with comparable climatic variables produced similar data. Therefore, to illustrate how differences in incoming global radiation $(\mathrm{G} \downarrow)$ affected the energy balance of each surface (and therefore gas exchange of trees over each surface), only morning-to-evening data from 1 Aug. 1995 (sunny day) and 26 July 1996 (partly cloudy day) will be presented.
Grass reference evapotranspiration $\left(\mathrm{ET}_{\mathrm{O}}\right)$ was calculated for each experiment using $\mathrm{ET}_{\mathrm{O}}$ calculation software (Allen, 1994). Climatic variables required to calculate $\mathrm{ET}_{\mathrm{O}}$ were total daily incoming global shortwave radiation $\left(\mathrm{MJ} \cdot \mathrm{m}^{-2} \cdot \mathrm{d}^{-1}\right)$, daily maximum and minimum $\mathrm{T}_{\mathrm{A}}\left({ }^{\circ} \mathrm{C}\right)$, daily maximum and minimum $\mathrm{RH}$ $(\%)$, and average daily $\mathrm{u}\left(\mathrm{m} \cdot \mathrm{s}^{-1}\right)$. Climatic variables used to calculate $\mathrm{ET}_{\mathrm{O}}$ were collected from a permanent weather station located $300 \mathrm{~m}$ east of experimental plots. This weather station was surrounded by a minimum of $100 \mathrm{~m}$ of irrigated turf. All variables were measured $2 \mathrm{~m}$ above the surface. Weather station components were of the same make and model as components used in experimental plots. Reference evapotranspiration was calculated for a well watered, nonstressed, cool-season grass using the Penman-Monteith equation with an assumed crop height of $0.12 \mathrm{~m}$, an albedo of 0.23 , and a fixed surface resistance of $70 \mathrm{~s} \cdot \mathrm{m}^{-1}$.

Thirty-minute means for $\mathrm{G} \downarrow, \mathrm{T}_{\mathrm{S}}, \mathrm{T}_{\mathrm{O}}, \mathrm{S}_{\mathrm{F}}, \mathrm{LVPD}, \mathrm{RH}$, and $\mathrm{T}_{\mathrm{A}}$, along with cycle means for $g_{s}$, and estimated tree water loss were plotted against time of day. Total estimated tree water loss for each tree was taken as the sum of all measuring cycles throughout the day. Full sun midday $P_{n}$ results for $4 \mathrm{~d}$; midday estimated tree water loss totals, $\mathrm{T}_{\mathrm{L}}, \mathrm{LVPD}, g_{s}$, and total estimated tree water loss data for $2 \mathrm{~d}$; weekly $\psi_{\mathrm{L}}$; daily $\mathrm{K}_{\mathrm{C}}$ values; and all growth data were subjected to analysis of variance appropriate for a split plot design ( surface treatment $=$ whole plot, species $=$ split plot $)($ SAS Inst., Inc., 1996). If significant differences were found, means were separated by Fisher's least significance difference procedure $(P$ $<0.05)$. Stomatal conductance versus LVPD and total leaf area versus trunk diameter data were analyzed by regression analysis. Linear or quadratic curves were selected according to significance of the equation and coefficient of determination $\left(R^{2}\right)$ value (SAS Inst., Inc., 1996).

\section{Results}

Climatic variables during morning-to-evening measurements differed between representative days. On 1 Aug. 1995 and 26 July 1996, G $\downarrow$ increased from $\approx 250 \mathrm{~W} \cdot \mathrm{m}^{-2}$ at $0800 \mathrm{HR}$ until $1400 \mathrm{HR}$ when $\mathrm{G} \downarrow$ peaked at $\approx 1300 \mathrm{~W} \cdot \mathrm{m}^{-2}$ (Fig. 1). However, on 26 July 1996 cloud cover increased in the early afternoon. Therefore, G $\downarrow$ decreased more rapidly on 26 July 1996 than on Aug. 1995. Total $\mathrm{G} \downarrow$ for the time period that experiments were performed were 43.4 MJ $\cdot \mathrm{m}^{-2}$ on 1 Aug. 1995 and $38.6 \mathrm{MJ} \cdot \mathrm{m}^{-2}$ on 26 July 1996. Throughout each day, RH patterns were similar, but on 1 Aug. 1995 air was drier compared to air on 26 July 1996 (Fig. 1). Air temperature on 26 July 1996 was greater, but more variable than TA on 1 Aug. 1995. Maximum-minimum TA for the time period that experiments were performed were $31.5^{\circ} \mathrm{C} / 7.9^{\circ} \mathrm{C}$ for $1 \mathrm{Aug}$. 1995 and $34.6{ }^{\circ} \mathrm{C} / 13.4^{\circ} \mathrm{C}$ for 26 July 1996 (Fig. 1). Mean u on 1 Aug. 1995 was $1.3 \mathrm{~m} \cdot \mathrm{s}^{-1}$ while mean u on 26 July 1996 was 0.7 $\mathrm{m} \cdot \mathrm{s}^{-1}$. Greater $\mathrm{G} \downarrow$ and $\mathrm{u}$ along with lower RH on 1 Aug. 1995 increased $\mathrm{ET}_{\mathrm{O}}$ on 1 Aug. 1995 compared to 26 July 1996 (Table. 1). Reference evapotranspiration on 1 Aug. 1995 was $5.7 \mathrm{~mm}$ while $\mathrm{ET}_{\mathrm{O}}$ for 26 July 1996 was $5.1 \mathrm{~mm}$.

Surface energy balance also differed between surface treatments and the day that data were gathered. Except in the early morning $(0700$ to $0800 \mathrm{HR}), \mathrm{T}_{\mathrm{S}}$ for mulch was greater than $\mathrm{T}_{\mathrm{S}}$ for turf on $1 \mathrm{Aug}$. 1995 and 26 July 1996 (Fig. 2). On 1 Aug. 1995, mulch $T_{S}$ ranged from 3.2 to $64.5^{\circ} \mathrm{C}$ while on 26 July 1996 , mulch $\mathrm{T}_{\mathrm{S}}$ ranged from 11.1 to $61.5^{\circ} \mathrm{C}$. Turf $\mathrm{T}_{\mathrm{S}}$ ranged from 11.2 to $29.4{ }^{\circ} \mathrm{C}$ on 1 Aug. 1995 and from 13.3 to $33.8^{\circ} \mathrm{C}$ on 26 July 1996 (Fig. 2).

Below each surface, $S_{F}$ and $T_{O}$ had similar trends. At $1400 \mathrm{HR}$ 


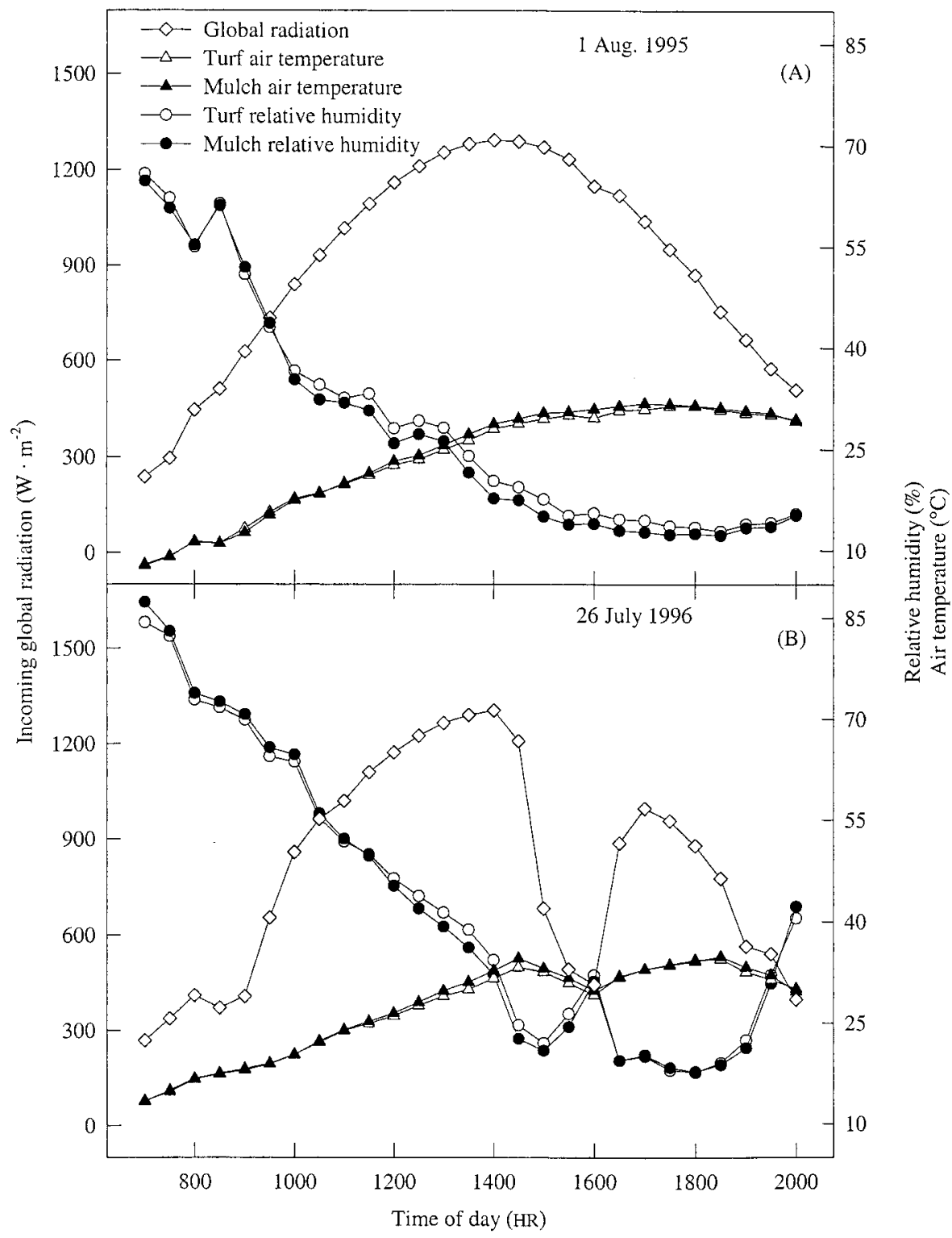

(time of maximum $\mathrm{G} \downarrow$ ), $\mathrm{S}_{\mathrm{F}}$ below turf was nearly three times greater than $S_{\mathrm{F}}$ below mulch on both 1 Aug. 1995 and 26 July 1996 (Fig. 2). Total $\mathrm{S}_{\mathrm{F}}$ for each day was comparable between experiment days but differed between surface treatments. On 1 Aug. 1995, sensors recorded 1.7 and $0.7 \mathrm{MJ} \cdot \mathrm{m}^{-2}$ below the turf and mulch surfaces, while on 26 July 1996, 1.8 and $0.7 \mathrm{MJ} \cdot \mathrm{m}^{-2}$ were measured under turf and mulch surfaces. Soil temperature in the morning and early afternoon on 1 Aug. 1995 and 26 July 1996 was similar between the two surfaces. However, as G $\downarrow$ reached a maximum in early afternoon, $T_{O}$ was greater below turf when compared to $T_{0}$ below mulch, and remained 1.0 or $2.0^{\circ} \mathrm{C}$ greater throughout the measuring period (Fig. 2). Effects of $T_{S}$ and $S_{F}$ on surface energy flux are clearly seen when total daily $\mathrm{L} \uparrow$ is calculated for each surface treatment. Total L $\uparrow$ for 1 Aug. 1995 was 20.1 and 26.3 $\mathrm{MJ} \cdot \mathrm{m}^{-2}$ for turf and mulch surfaces, while total $\mathrm{L} \uparrow$ for 26 July 1996 was 21.1 and 25.1 $\mathrm{MJ} \cdot \mathrm{m}^{-2}$ for turf and mulch surfaces.

Weekly predawn $\psi_{\mathrm{L}}$ data indicated that trees were not under water stress and that $\psi_{\mathrm{L}}$ was similar for trees over turf and for each tree species (data not presented). After being transplanted, weekly $\psi_{\mathrm{L}}$ for each species was near $-0.5 \mathrm{MPa}$ and remained close to this point for several weeks. However, by mid-June $1995, \psi_{\mathrm{L}}$ recovered to about -0.3 $\mathrm{MPa}$ and remained near this level for the remainder of the experiment.

During each growing season, tree gas exchange was closely associated with surface energy balance. Midday (1300 to 1500 HR) $\mathrm{T}_{\mathrm{L}}$ on 1 Aug. 1995 (full sun day) was $32.2^{\circ} \mathrm{C}$ and $30.2{ }^{\circ} \mathrm{C}$ for leaves over mulch and turf (Table 2). However, on 26 July 1996 (partly cloudy day), midday $T_{L}$ was not different for leaves over mulch compared to leaves over turf (Table 2). For species,

Fig. 1. Morning-to-evening incoming global radiation, air temperature, and relative humidity for (A) 1 Aug. 1995 and (B) 26 July 1996.

Table 1. Midday (1300 to1500 HR) mean estimated water loss, daily reference evapotranspiration (ET $_{\mathrm{O}}$, daily estimated water loss, and daily crop coefficients for irrigated Acer platanoides 'Emerald Queen' and Tilia cordata 'Greenspire' trees growing over turf and pine bark surfaces under full-sun (1 Aug. 1995) and cloudy (26 July 1996) climatic conditions.

\begin{tabular}{|c|c|c|c|c|c|c|c|c|}
\hline & \multicolumn{2}{|c|}{$\begin{array}{c}\text { Midday } \\
\text { estimated water loss } \\
(\mathrm{mm})\end{array}$} & \multicolumn{2}{|c|}{$\begin{array}{l}\mathrm{ET}_{\mathrm{O}} \\
(\mathrm{mm})\end{array}$} & \multicolumn{2}{|c|}{$\begin{array}{c}\text { Daily } \\
\text { estimated water loss } \\
(\mathrm{mm})\end{array}$} & \multicolumn{2}{|c|}{$\begin{array}{l}\text { Daily crop } \\
\text { coefficient }\end{array}$} \\
\hline & 1 Aug. & 26 July & 1 Aug. & 26 July & 1 Aug. & 26 July & 1 Aug. & 26 July \\
\hline \multicolumn{9}{|l|}{ Surface } \\
\hline Turf & $0.11 \mathrm{a}^{\mathrm{z}}$ & 0.22 & 5.7 & 5.1 & $0.70 \mathrm{a}$ & 1.44 & $0.12 \mathrm{a}$ & 0.28 \\
\hline Mulch & $0.04 \mathrm{~b}$ & 0.21 & & & $0.38 \mathrm{~b}$ & 1.47 & $0.07 \mathrm{~b}$ & 0.31 \\
\hline \multicolumn{9}{|l|}{ Species } \\
\hline Acer platanoides & 0.07 & $0.16 \mathrm{~b}$ & & & 0.51 & $1.04 \mathrm{~b}$ & 0.09 & $0.20 \mathrm{~b}$ \\
\hline Tilia cordata & 0.07 & $0.27 \mathrm{a}$ & & & 0.57 & $1.86 \mathrm{a}$ & 0.10 & $0.37 \mathrm{a}$ \\
\hline Significance & \multicolumn{8}{|c|}{$P>\mathrm{F}$} \\
\hline Surface & 0.002 & 0.794 & --- & --- & 0.001 & 0.813 & 0.001 & 0.813 \\
\hline Species & 0.953 & 0.083 & & & 0.273 & 0.001 & 0.273 & 0.001 \\
\hline Species $\times$ surface & 0.632 & 0.813 & --- & --- & 0.162 & 0.915 & 0.167 & 0.915 \\
\hline
\end{tabular}

${ }^{\mathrm{z}}$ Mean separation between surface treatments and between species by LSD $(P=0.05)$. 


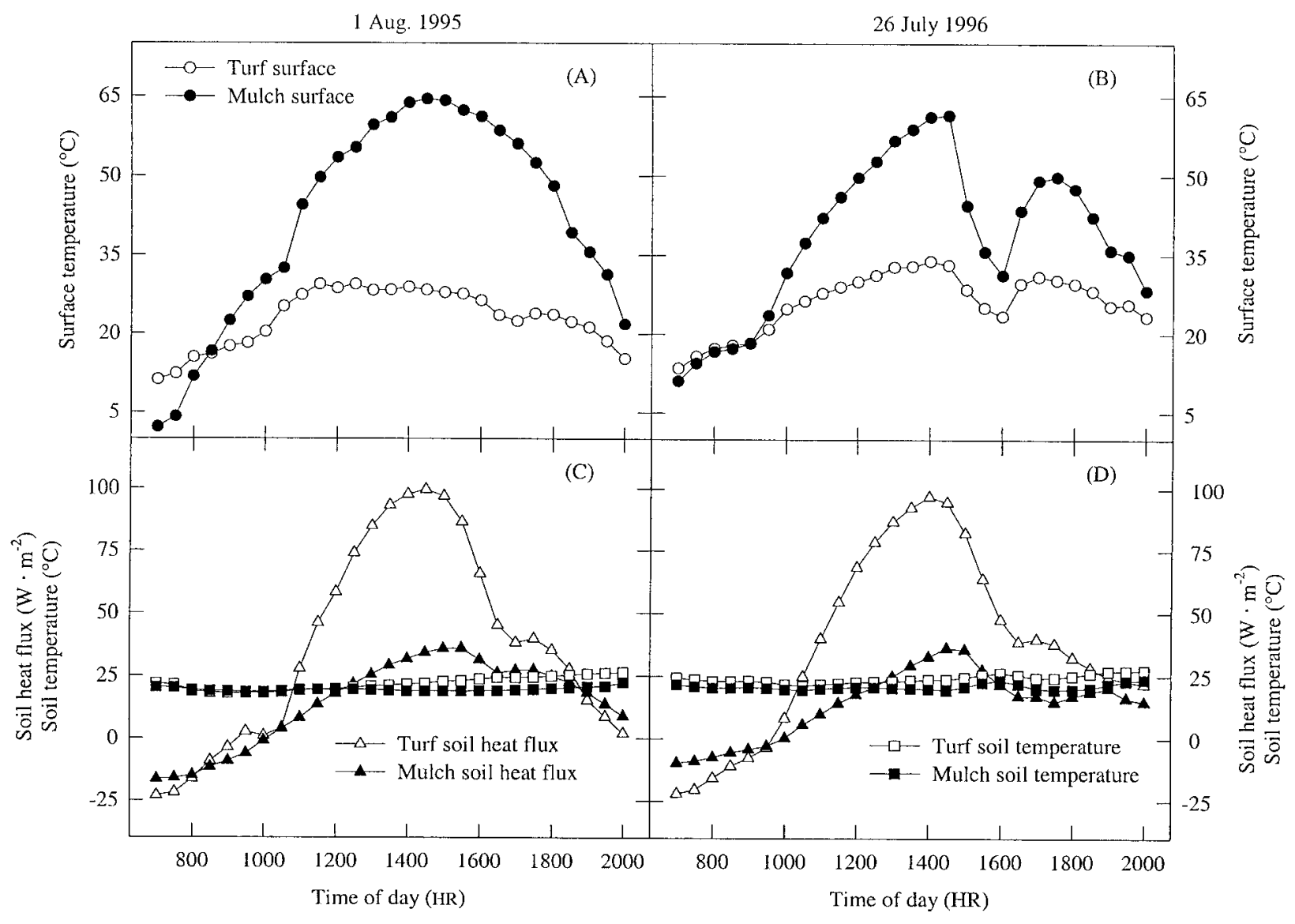

Fig. 2. (A and B) morning-to-evening surface temperature, $(\mathbf{C}$ and $\mathbf{D})$ soil heat flux, and $(\mathbf{C}$ and $\mathbf{D})$ soil temperature for turf and pine bark mulch surfaces on (A and C) 1 Aug. 1995 and (B and D) 26 July 1996

there were no differences in midday $\mathrm{T}_{\mathrm{L}}$ on either day. Midday LVPD on 1 Aug. 1995 also was greater for leaves over mulch compared to leaves over turf. Midday LVPD for leaves over mulch was $4.8 \mathrm{kPa}$ compared to $3.8 \mathrm{kPa}$ for trees over turf (Table 2). For 26 July 1996, there was no difference in midday LVPD between surface treatments.

On 1 Aug. 1995, midday $g_{s}$ was $47.1 \mathrm{mmol} \cdot \mathrm{m}^{-2} \cdot \mathrm{s}^{-1}$ for leaves over turf compared to $18.2 \mathrm{mmol} \cdot \mathrm{m}^{-2} \cdot \mathrm{s}^{-1}$ for leaves over mulch (Table 2). For 26 July 1996, leaves over turf had slightly greater $g_{s}$, although the difference was not significant. Between species there were no $g_{s}$ differences on 1 Aug. 1995. One year later on 26 July 1996 , midday $g_{s}$ for linden leaves was $101.0 \mathrm{mmol} \cdot \mathrm{m}^{-2} \cdot \mathrm{s}^{-1}$, while midday $g_{s}$ for maple leaves was $66.0 \mathrm{mmol} \cdot \mathrm{m}^{-2} \cdot \mathrm{s}^{-1}$ (Table 2). Estimated midday water loss was similar to $g_{s}$ results. Under full sun climatic conditions (1 Aug. 1995), estimated midday water loss was $0.11 \mathrm{~mm}$ for trees over turf and $0.04 \mathrm{~mm}$ for trees over mulch (Table 1). With cloudy conditions (26 July 1996), there were no differences in midday estimated water loss between surface treatments. On 1 Aug. 1995, under full sun conditions estimated midday water loss for maple and linden trees was not different. However, on 26 July 1996, midday estimated water loss for linden trees was $0.27 \mathrm{~mm}$ compared to estimated water loss of $0.16 \mathrm{~mm}$ for maple trees (Table 1 ).

In 1995 and 1996, midday, full sun $P_{n}$ was greater for leaves over turf when compared to leaves over mulch (Table 3 ). For example, on 16 Aug. 1995, midday $P_{n}$ for leaves over turf was 9.5 $\mathrm{mmol} \cdot \mathrm{m}^{-2} \cdot \mathrm{s}^{-1}$. On the same day, leaves growing over mulch had midday $P_{n}$ of $4.7 \mathrm{mmol} \cdot \mathrm{m}^{-2} \cdot \mathrm{s}^{-1}$. In 1995 , Norway maple leaves had slightly greater midday $P_{n}$ when compared to linden leaves. In 1996 , this trend was reversed, as midday $P_{n}$ for linden leaves was $>40 \%$ greater than midday $P_{n}$ for maple leaves (Table 3 ).

Morning-to-evening data from 1 Aug. 1995 and 26 July 1996 also indicate that tree gas exchange was correlated with the energy balance of the surface surrounding the tree. Throughout each day, $\mathrm{T}_{\mathrm{L}}$ was greatest for leaves over mulch (Fig. 3). Leaf-to-air vapor pressure difference was greater during full sun climatic conditions and for leaves over mulch (Fig. 3). On 1 Aug. 1995 (full sun day), LVPD reached a maximum of 4.6, 4.2, 4.8, and $4.2 \mathrm{kPa}$ for maple leaves over mulch, maple leaves over turf, linden leaves over mulch, and linden leaves over turf, respectively (Fig. 3). However, because of cloud cover and greater RH in the afternoon, LVPD on 26 July 1996 was more variable and reached maximums of 4.1,3.9,4.2, and 3.4 , for maple leaves over mulch, maple leaves over turf, linden leaves over mulch, and linden leaves over turf, respectively (Fig. 3). On each study day, $g_{s}$ for maple leaves over turf and mulch, and linden leaves over mulch, decreased as LVPD increased. However on 26 July 1996, linden leaves over turf did not display this inverse relationship (Figs. 3 and 4).

Each day morning-to-evening measurements were gathered, leaves over turf had greater $g_{s}$ than leaves over mulch (Fig. 3). Stomatal conductance on 1 Aug. 1995 for leaves over turf was near $60.0 \mathrm{mmol} \cdot \mathrm{m}^{-2} \cdot \mathrm{s}^{-1}$ for maple trees and $50.0 \mathrm{mmol} \cdot \mathrm{m}^{-2} \cdot \mathrm{s}^{-1}$ for linden trees over the entire interval (Fig. 3). However, $g_{s}$ throughout the day for leaves of each species over mulch was $\approx 30.0$ $\mathrm{mmol} \cdot \mathrm{m}^{-2} \cdot \mathrm{s}^{-1}$. Results from 26 July 1996 , indicate that until early afternoon, $g_{s}$ for maple leaves over turf was up to two times greater than $g_{s}$ for maple leaves over mulch (Fig. 3). However, after $\approx 1400 \mathrm{HR}, g_{s}$ for maple leaves over turf decreased while $g_{s}$ for 
Table 2. Midday (1300 to $1500 \mathrm{HR}$ ) mean leaf temperature, leaf-to-air vapor pressure difference (LVPD), and stomatal conductance (sunlit and shade leaves) for irrigated Acer platanoides 'Emerald Queen' and Tilia cordata 'Greenspire' trees growing over turf and pine bark mulch.

\begin{tabular}{|c|c|c|c|c|c|c|}
\hline & \multicolumn{2}{|c|}{$\begin{array}{l}\text { Leaf temperature } \\
\qquad\left({ }^{\circ} \mathrm{C}\right)\end{array}$} & \multicolumn{2}{|c|}{$\begin{array}{l}\text { LVPD } \\
(\mathrm{kPa})\end{array}$} & \multicolumn{2}{|c|}{$\begin{array}{l}\text { Stomatal conductance } \\
\left(\mathrm{mmol} \cdot \mathrm{m}^{-2} \cdot \mathrm{s}^{-1}\right)\end{array}$} \\
\hline & 1 Aug. & 26 July & 1 Aug. & 26 July & 1 Aug. & 26 July \\
\hline \multicolumn{7}{|l|}{ Surface } \\
\hline Turf & $30.2 b^{z}$ & 27.9 & $3.8 \mathrm{~b}$ & 2.7 & $47.1 \mathrm{a}$ & 94.4 \\
\hline Mulch & $32.2 \mathrm{a}$ & 28.3 & $4.9 \mathrm{a}$ & 3.1 & $18.2 \mathrm{~b}$ & 73.2 \\
\hline \multicolumn{7}{|l|}{ Species } \\
\hline Acer platanoides & 30.8 & 29.0 & 4.1 & 3.0 & 37.4 & $66.3 \mathrm{~b}$ \\
\hline Tilia cordata & 31.4 & 28.3 & 4.2 & 2.8 & 27.6 & $101.1 \mathrm{a}$ \\
\hline Significance & \multicolumn{6}{|c|}{$P>\mathrm{F}$} \\
\hline Surface & 0.004 & 0.284 & 0.001 & 0.232 & 0.003 & 0.207 \\
\hline Species & 0.190 & 0.583 & 0.210 & 0.582 & 0.107 & 0.049 \\
\hline Species $\times$ surface & 0.671 & 0.983 & 0.676 & 0.980 & 0.979 & 0.946 \\
\hline
\end{tabular}

${ }^{\mathrm{z}}$ Mean separation between surface treatments and between species by LSD $(P=0.05)$.

Table 3. Midday (1300 to $1500 \mathrm{HR}$ ) photosynthetic rate (sunlit leaves) for irrigated Acer platanoides 'Emerald Queen' and Tilia cordata 'Greenspire' trees growing over turf and pine bark mulch for $2 \mathrm{~d}$ in 1995 and 1996.

\begin{tabular}{|c|c|c|c|c|}
\hline & \multicolumn{4}{|c|}{$\begin{array}{l}\text { Photosynthetic rate } \\
\quad\left(\mu \mathrm{mol} \cdot \mathrm{m}^{-2} \cdot \mathrm{s}^{-1}\right)\end{array}$} \\
\hline & \multicolumn{2}{|c|}{1995} & \multicolumn{2}{|c|}{1996} \\
\hline & 3 Aug. & 16 Aug. & 9 Aug. & $16 \mathrm{Aug}$. \\
\hline \multicolumn{5}{|l|}{ Surface } \\
\hline Turf & $9.1 \mathrm{a}^{\mathrm{z}}$ & $9.5 \mathrm{a}$ & $7.3 \mathrm{a}$ & $7.5 \mathrm{a}$ \\
\hline Mulch & $3.6 \mathrm{~b}$ & $4.7 \mathrm{~b}$ & $4.9 \mathrm{~b}$ & $5.1 \mathrm{~b}$ \\
\hline \multicolumn{5}{|l|}{ Species } \\
\hline Acer platanoides & 7.7 & 7.6 & $4.4 \mathrm{~b}$ & $4.4 \mathrm{~b}$ \\
\hline Tilia cordata & 4.9 & 6.6 & $7.8 \mathrm{a}$ & $8.1 \mathrm{a}$ \\
\hline Significance & \multicolumn{4}{|c|}{$P>\mathrm{F}$} \\
\hline Surface & 0.030 & 0.003 & 0.008 & 0.005 \\
\hline Species & 0.248 & 0.431 & 0.007 & 0.001 \\
\hline Species $\times$ surface & 0.760 & 0.959 & 0.824 & 0.876 \\
\hline
\end{tabular}

${ }^{\mathrm{z}}$ Mean separation between surface treatments and between species by LSD $(P=0.05)$.

maple leaves over mulch remained constant. Stomatal conductance for linden leaves over turf and mulch on 26 July 1996 was similar until shortly after $1000 \mathrm{HR}$ (Fig. 4). After this time, $g_{s}$ for linden leaves over turf generally increased and reached an afternoon maximum of $158.0 \mathrm{mmol} \cdot \mathrm{m}^{-2} \cdot \mathrm{s}^{-1}$, while $g_{s}$ for linden leaves over mulch decreased and reached an afternoon maximum of $100.0 \mathrm{mmol} \cdot \mathrm{m}^{-2} \cdot \mathrm{s}^{-1}$ (Fig. 3).

Under full sun climatic conditions (1 Aug. 1995), total daily estimated tree water loss was greatest for trees over turf. Tree water loss was $0.69 \mathrm{~mm}$ for trees over turf and $0.38 \mathrm{~mm}$ for trees over mulch (Table 1). However, when climatic conditions were partly cloudy (26 July 1996) there were no differences in tree water loss between surface treatments. Estimated tree water loss for trees over turf and mulch were 1.44 and $1.57 \mathrm{~mm}$ (Table 1). Differences in estimated tree water loss were not found between species in 1995, but were found in 1996. On 26 July 1996, estimated water loss for linden trees was $44 \%$ greater than estimated water loss for maple trees (Table 1). Tree transpiration generally followed, but was less than, $\mathrm{ET}_{\mathrm{O}}$ (Fig. 5). However, during cloudy conditions on 26 July 1996 (1400 to $1700 \mathrm{HR}$ ), tree water loss was greater than or similar to $\mathrm{ET}_{\mathrm{O}}$. Crop coefficients for 1 Aug. 1995 were greater for trees over turf $\left(K_{C}=0.12\right)$ compared to trees over mulch $\left(\mathrm{K}_{\mathrm{C}}=0.07\right)$ with no differences between tree species (Table 2). On 26 July $1996 \mathrm{~K}_{\mathrm{C}}$ values for trees over mulch
$\left(\mathrm{K}_{\mathrm{C}}=0.31\right)$ were comparable to $\mathrm{K}_{\mathrm{C}}$ values for trees over turf $\left(\mathrm{K}_{\mathrm{C}}\right.$ $=0.28)$ and $\mathrm{K}_{\mathrm{C}}$ for linden $\left(\mathrm{K}_{\mathrm{C}}=0.37\right)$ was greater than $\mathrm{K}_{\mathrm{C}}$ for maple $\left(\mathrm{K}_{\mathrm{C}}=0.20\right)($ Table 1$)$.

Tree growth was also affected by surface treatment. In 1995, there were no surface treatment effects on shoot elongation, but maple trees had nearly three times more shoot growth when compared to linden trees (Table 4). Shoot elongation for maple trees in 1996 and both tree species in 1997 was less for trees grown over mulch compared to trees grown over turf (Table 4). Stem area increase was influenced by surface treatment only in 1995 . For each of the next 2 years, stem area increase was greater for maple trees when compared to linden trees. In 1995, leaf area was similar for trees over turf and trees over mulch. Leaf area in 1996 was $34 \%$ greater for maple trees over turf compared to maple trees over mulch, but leaf area for linden trees over turf and mulch was similar. Following the final growing season, leaf area was once again greater for trees over turf compared to trees over mulch (Table 4). Leaf area for trees over turf was $17.2 \mathrm{~m}^{2}$, while leaf area for trees growing over mulch was $12.9 \mathrm{~m}^{2}$.

\section{Discussion}

For turf and pine bark mulch, differences in surface energy balance were clear. Thermal conductivity of a substance is a 


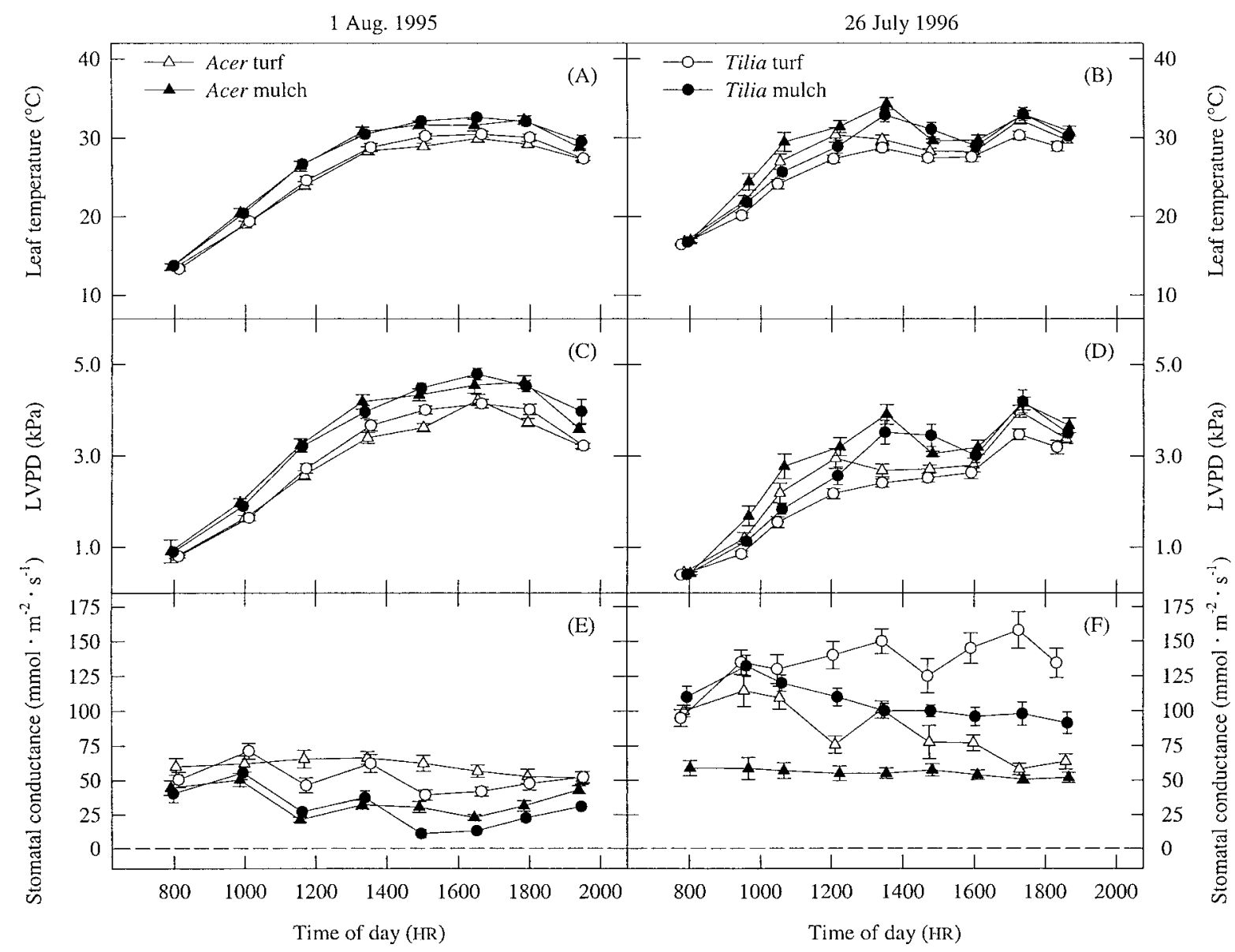

Fig. 3. (A and B) morning-to-evening leaf temperature, (C and $\mathbf{D})$ leaf-to-air vapor pressure difference (LVPD), ( $\mathbf{E}$ and $\mathbf{F}$ ) and stomatal conductance for transplanted Acer platanoides 'Emerald Queen' and Tilia cordata 'Greenspire' trees (sunlit and shade leaves) growing over turf and pine bark mulch on $(\mathbf{A}, \mathbf{C}$, and E) 1 Aug. 1995 and (B, D, and F) 26 July 1996. Each symbol is the mean of 24 measurements. Vertical bars represent SES of the mean (SE is smaller than symbol when error bar is not shown).

measure of its ability to transmit heat (Oke, 1978). Thermal conductivity of turf and mulch was estimated as 0.85 and 0.12 $\mathrm{W} \cdot \mathrm{m}^{-1} \cdot \mathrm{C}^{-1}$, respectively. Estimated turf $\mathrm{K}$ was similar to values found for many dry soils (Oke, 1978). Estimated $\mathrm{K}$ for mulch was comparable to the mean $\mathrm{K}$ of light wood $\left(0.09 \mathrm{~W} \cdot \mathrm{m}^{-1} \cdot \mathrm{C}^{-1}\right)$ and still air $\left(0.02 \mathrm{~W} \cdot \mathrm{m}^{-1} \cdot \mathrm{C}^{-1}\right)($ Oke, 1978). Although water content has a great influence on $\mathrm{K}$ (Oke, 1978), water content of pine bark mulch was not calculated. However, visual observations of pine bark mulch throughout each summer indicated that the mulch surface was dry the first $10 \mathrm{~cm}$ below the surface. Near the soilpine bark mulch interface, mulch and soil were generally very moist throughout the growing season. Due to lower K, less energy was conducted into the soil below mulch than into the soil below turf. As a result, soil below turf generally had greater $S_{F}$ and $T_{O}$ (Fig. 2). Since turf dissipated absorbed radiation as latent heat (Baver et al., 1972), evaporative cooling also contributed to the differences in surface energy balance. Surface temperature of turf was generally cooler than $T_{S}$ of mulch and would have less sensible heat and L $\uparrow$ flux than the mulch surface (Fig. 2). Soil heat flux below turf also reached greater extremes when compared to $S_{\mathrm{F}}$ under pine bark mulch (Fig. 2). Fraedrich and Ham (1982) and Watson and Kupkowski (1991) report similar results.

Due to greater sensible heat flux from mulch compared to turf, it was thought that $\mathrm{T}_{\mathrm{A}}$ and $\mathrm{RH}$ over each site would be different (Geiger, 1973). However, differences in $\mathrm{T}_{\mathrm{A}}$ and $\mathrm{RH}$ between sites were not detected (Fig. 1). Similar $\mathrm{T}_{\mathrm{A}}$ and $\mathrm{RH}$ between sites was possibly due to rapid mixing and dilution of air between sites as a result of their relatively small area and close proximity (Kjelgren and Montague, 1998; Monteith and Unsworth, 1990). If there were greater distance between surfaces, and if surfaces with greater fetch had been utilized, climatic variables over each surface would have likely been more characteristic of each individual surface (Allen et al., 1994). For characteristic surface vapor and heat fluxes to be measured, an equilibrium layer must form over the surface to insure that data being collected are not affected by different surfaces upwind (Allen et al., 1994). To achieve an equilibrium layer, ratios of 50:1 to 200:1 are suggested for fetch length to height of the measuring equipment (Allen, 1996). Since fetch for each surface was small, it is likely that weather data sensors recorded climatic data $\left(T_{A}\right.$ and $\left.R H\right)$ from surfaces upwind that were not representative of microclimates over each surface treatment.

Although microclimate differences above each surface do not appear large enough to modify tree gas exchange and growth, $\mathrm{T}_{\mathrm{S}}$ differences between surfaces were great enough to affect trees. Greater $T_{S}$ for mulch resulted in greater $\mathrm{L} \uparrow$ flux from the mulch surface compared to the turf surface (Fig. 2). As a result, leaves over mulch intercepted more longwave radiation and had greater $\mathrm{T}_{\mathrm{L}}$ than leaves over turf. Because $\mathrm{T}_{\mathrm{L}}$ strongly influences LVPD (Jones, 1992), stomatal response to increased evaporative demand on leaves may be explained by differences in $T_{L}$. Throughout each day experiments were conducted, leaves over mulch generally had greater $T_{L}$ and LVPD than leaves over turf (Fig. 3) 


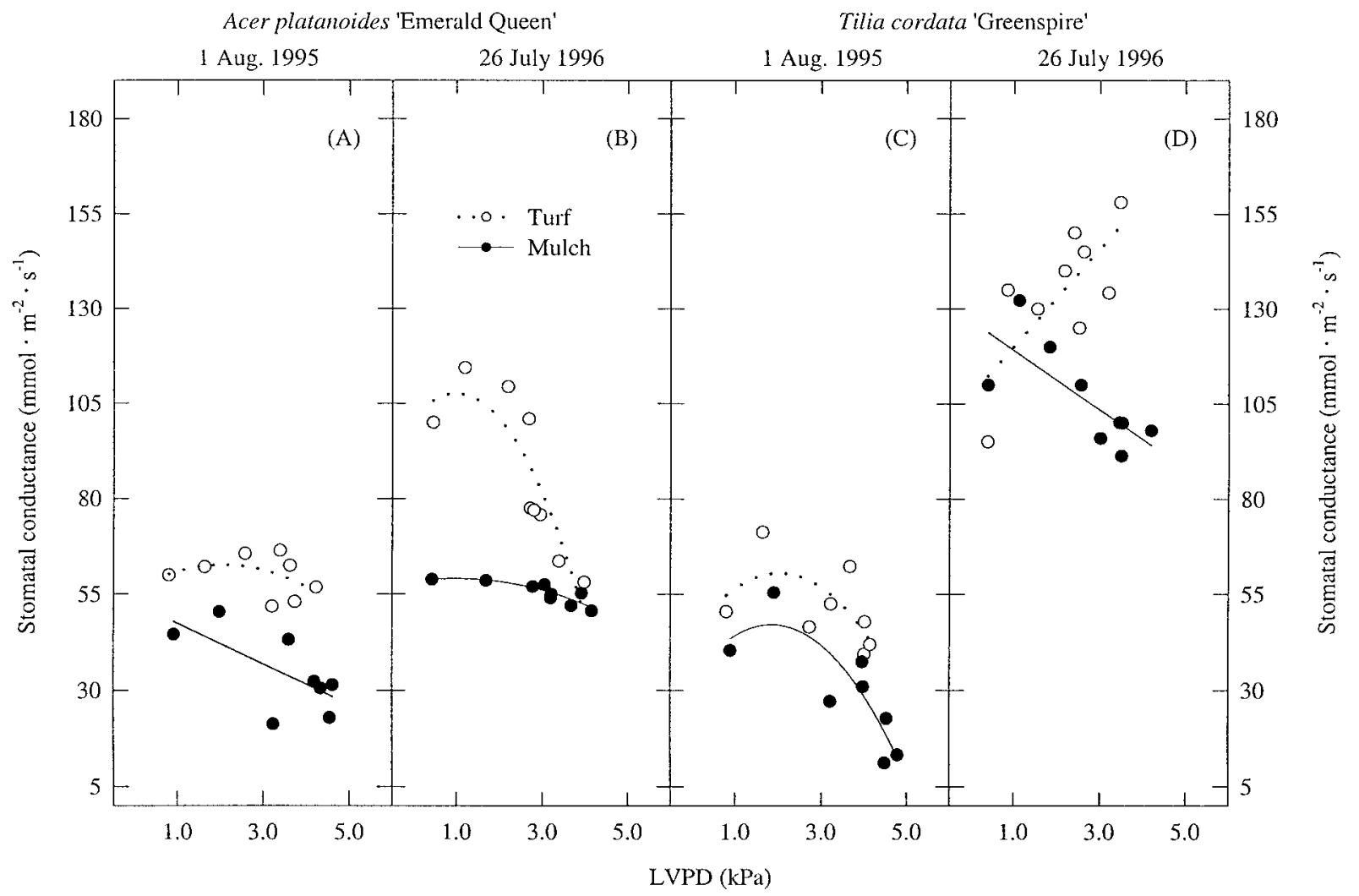

Fig. 4. Actual and predicted values for effect of leaf-to-air vapor pressure difference (LVPD) on stomatal conductance of transplanted Acer platanoides 'Emerald Queen' and Tilia cordata 'Greenspire' trees growing over turf and pine bark mulch on (A and C) 1 Aug. 1995 and (B and D) 26 July 1996. Predicted regression line equations are followed by $R^{2}$ values and significance for the equation: (A) 1 Aug. 1995 A. platanoides over turf: $g_{s}=56.2+6.2 \mathrm{x}-1.5 \mathrm{x}^{2}, R^{2}$ $=0.65, P=0.063$; (A) 1 Aug. 1995 A platanoides over mulch: $g_{s}=52.7-5.3 \mathrm{x}$, $R^{2}=0.55, P=0.066$; (B) 26 July 1996 A. platanoides over turf: $g_{s}=102.5+10.6 \mathrm{x}$ $-5.9 \mathrm{x}^{2}, R^{2}=0.75, P=0.016$; (B) 26 July 1996 A. platanoides over mulch: $g_{s}=$ $58.5+1.6 \mathrm{x}-0.8 \times 2, R^{2}=0.78, P=0.011 ;(\mathbf{C}) 1$ Aug. 1995 T. cordata over turf: $g_{s}=44.5+15.8 \mathrm{x}-3.9 \mathrm{x}^{2}, R^{2}=0.38, P=0.310 ;($ C) 1 Aug. 1995 T. cordata over mulch: $g_{s}=33.4+14.7 \mathrm{x}-3.9 \mathrm{x}^{2}, R^{2}=0.74, P=0.034$; (D) 26 July $1996 T$. cordata over turf: $g_{s}=107.5+12.8 \mathrm{x}, R^{2}=0.53, P=0.026 ; 26$ July $1996 T$. cordata over mulch: $g_{s}=126.9-7.8 \mathrm{x}, R^{2}=0.54, P=0.024$ (each symbol is the mean of 24 measurements).

and similar trends were observed over the 3 years of experiments. In a comparable experiment, Kjelgren and Montague (1998) reported greater $T_{L}$ and LVPD for containerized 'Patmore' green ash (Fraxinus pennsylvanica Marsh.) and 'Emerald Queen' Norway maple growing over asphalt compared to containerized trees growing over turf. Close et al. (1996a) and Zajicek and Heilman (1991) have also reported greater $T_{L}$ and LVPD for woody plants over nonvegetative surfaces compared to woody plants over vegetative surfaces.

Increased $\mathrm{T}_{\mathrm{L}}$ (and therefore LVPD) has a clear affect on stomatal behavior (Figs. 3 and 4). Although, stomatal sensitivity of woody plants to evaporative demand varies with species (Mooney and Chu, 1983), to reduce $\mathrm{E}$ as evaporative demand increases, stomata of many woody plants close when LVPD rises above a threshold level (Monteith, 1995; Mott and Parkhurst, 1991). This feedforward response to high LVPD (Farquhar, 1978) triggered stomatal closure (Farquhar, 1978; Turner et al., 1984) that reduced $g_{s}$ for maple leaves over turf and mulch on 1 Aug. 1995 and 26 July 1996 and linden leaves over mulch on 1 Aug. 1995. However for linden leaves over turf on 26 July 1996, high $g_{s}$ and low $\mathrm{T}_{\mathrm{L}}$ evidently lowered LVPD such that a threshold LVPD level was not reached. Increased $g_{s}$ in response to in- creased LVPD has been reported for several woody plant species (Marshall and Waring, 1984) and might be an adaptation to maximize $P_{n}$ in environments where soil water is nonlimiting.

Stomatal response to increased energy from the mulch surface affected estimated tree water loss. Equation [1] appears to estimate realistically water loss from isolated trees in an arid climate. On a day with little cloud cover (1 Aug. 1995), estimated tree water loss over turf was greater than estimated tree water loss over mulch (Table 1; Fig. 5). Increased $\mathrm{L} \uparrow$ from mulch increased $\mathrm{T}_{\mathrm{L}}$ and LVPD and decreased $g_{s}$ on leaves over mulch such that the threshold for stomatal closure (Farquhar, 1978; Turner et al., 1984) was reached earlier in the day and for a more prolonged time period than for leaves over turf (Fig. 3). During 3 years of experiments conducted under full sun conditions, trees over turf had greater water loss than trees over mulch. In an arid climate, Kjelgren and Montague (1998) reported similar results. They found greater water loss for containerized 'Patmore'green ash and 'Emerald Queen' Norway maple trees growing over turf compared to containerized trees growing over asphalt. Close et al. (1996b) and Kjelgren and Clark (1993) also found that urban trees in high-energy environments had greater LVPD and less water loss than trees in low-energy, rural environments. Depending on species stomatal sensitivity, an isolated tree intercepting $\mathrm{L} \uparrow$ from a nonvegetative, urban surface in a humid climate could have greater water loss than an isolated tree over a vegetative surface. This would be possible because the threshold for stomatal closure due to high evaporative demand would likely be reached later in the day, and have less duration, than in an arid climate such as Utah. Research on urban tree and shrub water loss in humid environments have reported such results (Heilman et al., 1989; Miller, 1980; Potts and Herrington, 1982; Zajicek and Heilman, 1991).

Such was not the case in our study. On 1 Aug. 1995 (full sun day), $K_{C}$ was less over mulch compared to turf due to increased LVPD and decreased $g_{s}$. However, because of decreased LVPD 


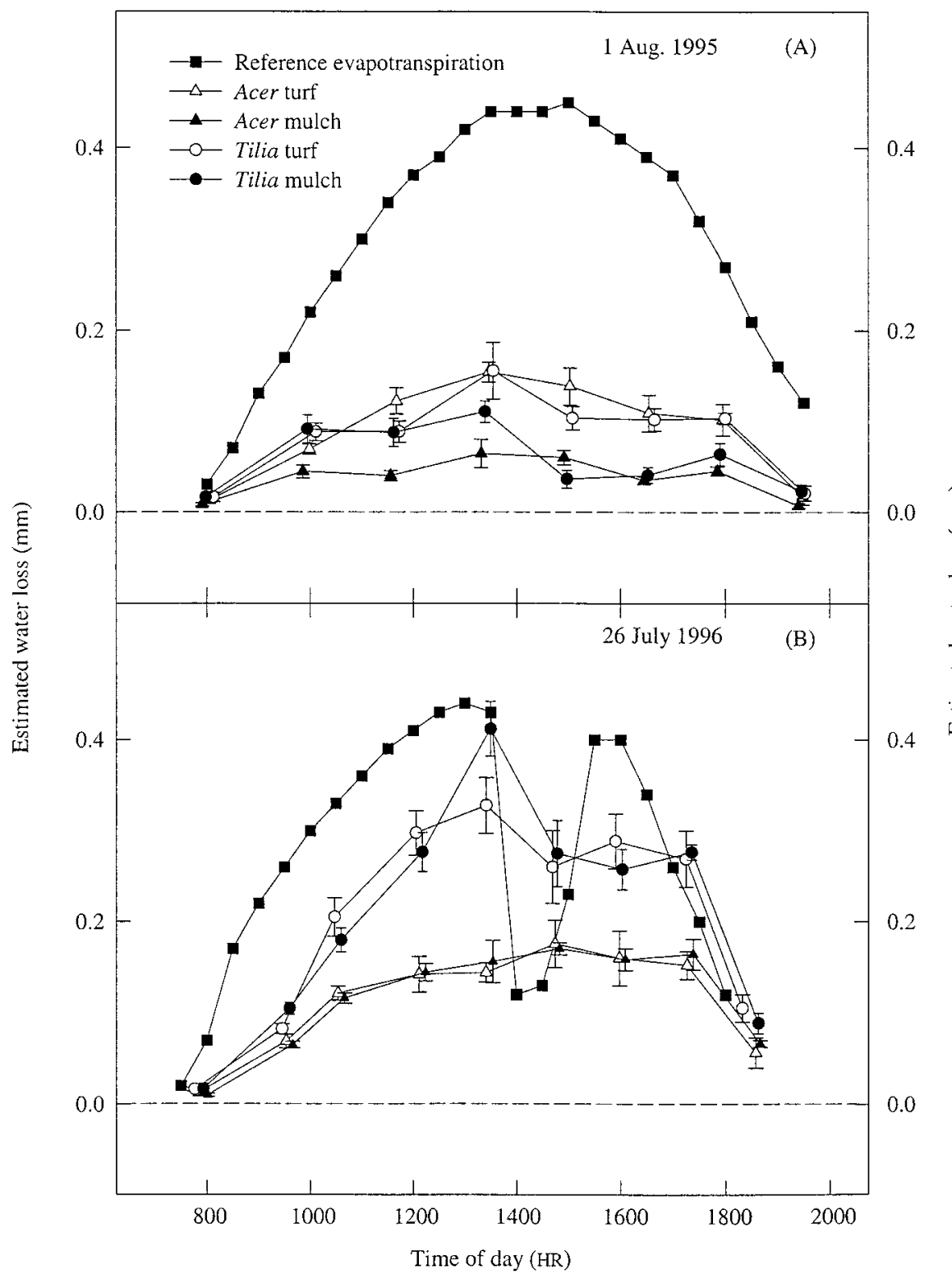

and increased $g_{s}$ on 26 July 1996 (partly cloudy day) compared to 1 Aug. $1995, \mathrm{~K}_{\mathrm{C}}$ values were not different between turf and mulch treatments. Because of greater water loss for linden than maple on 26 July 1996, $\mathrm{K}_{\mathrm{C}}$ for linden was greater than $\mathrm{K}_{\mathrm{C}}$ for maple. These $\mathrm{K}_{\mathrm{C}}$ values are comparable to reports of others (Garbesi, 1992; Levittet al., 1995). Differences in $\mathrm{K}_{\mathrm{C}}$ values between 1 Aug. 1995 and 26 July 1996 were likely due to differing climatic variables and increased water loss due to greater $\mathrm{A}_{\mathrm{T}}$. On 26 July 1996, even though $\mathrm{ET}_{\mathrm{O}}$ was less than on 1 Aug. 1995, trees responded to lower LVPD by increasing $g_{s}$ and $\mathrm{E}$ (Figs. 3 and 5; Table 1).

Estimating total tree water loss (and replacement amount) with a $\mathrm{K}_{\mathrm{C}}$ is not possible without knowledge of $A_{T}$. Nondestructive instruments to estimate $A_{T}$ of isolated trees have been developed. However, precision of these instruments has been questioned (Peper and McPherson, 1998). An alternative method is to develop a regression equation based on destructive sampling and measured tree parameters such as trunk diameter or area, crown height, or average crown diameter (Bacon and Zedaker, 1986; Nowak, 1996). For species in this study, $A_{T}$ and trunk area data from each tree for three growing seasons were used to develop a linear regression equation (SAS Institute, Inc., 1996). From these data, $A_{T}=(-13.1)+$ $(0.7 \mathrm{x})$ where $\mathrm{A}_{\mathrm{T}}$ is in $\mathrm{m}^{2}$ and $\mathrm{x}$ is trunk area at $0.30 \mathrm{~m}$ above soil level $\left(\mathrm{cm}^{2}\right)$. Coefficient of determination for the equation $\left(R^{2}=0.81\right)$ revealed good fit and is similar to work by Bacon and Zedaker (1986) and Nowak (1996) where $R^{2}$ values ranged from 0.64 to 0.98 . Once $A_{T}$ is determined, actual irrigation amount to apply can be calculated using

Fig. 5. Morning-to-evening estimated tree water loss and reference evapotranspiration patterns from (A) 1 Aug. 1995 and (B) 26 July 1996 for transplanted Acer platanoides 'Emerald Queen' and Tilia cordata 'Greenspire' trees growing over turf and pine bark mulch. Vertical bars represent SES (SE is smaller than symbol when error bar is not shown). the formula $E_{\mathrm{W}}=\left(\mathrm{ET}_{\mathrm{O}}\right) \times\left(\mathrm{K}_{\mathrm{C}}\right) \times\left(\mathrm{A}_{\mathrm{T}}\right)$ where $\mathrm{E}_{\mathrm{W}}$ is amount of water to apply $\left(\mathrm{m}^{3}\right), \mathrm{ET}_{\mathrm{O}}$ is in $\mathrm{m}$, and $\mathrm{A}_{\mathrm{T}}$ is in $\mathrm{m}^{2}$. Depending on soil type, available irrigation water, tree species, and daily $\mathrm{ET}_{\mathrm{O}}$, a daily,

Table 4. Shoot elongation, stem area increase, and total leaf area for irrigated Acer platanoides 'Emerald Queen' and Tilia cordata 'Greenspire' trees growing over turf and pine bark mulch for $2 \mathrm{~d}$ in 1995, 1996, and 1997.

\begin{tabular}{|c|c|c|c|c|c|c|c|c|c|c|c|}
\hline \multirow[b]{3}{*}{ Surface } & \multicolumn{4}{|c|}{$\begin{array}{l}\text { Shoot elongation } \\
\qquad(\mathrm{cm})\end{array}$} & \multicolumn{3}{|c|}{$\begin{array}{l}\text { Stem area increase } \\
\left(\mathrm{cm}^{2}\right)\end{array}$} & \multicolumn{4}{|c|}{$\begin{array}{l}\text { Total leaf area } \\
\qquad\left(\mathrm{m}^{2}\right)\end{array}$} \\
\hline & 1995 & \multicolumn{2}{|c|}{1996} & 1997 & 1995 & 1996 & 1997 & 1995 & \multicolumn{2}{|c|}{1996} & 1997 \\
\hline & & Acer & Tilia & & & & & & Acer & Tilia & \\
\hline Turf & $8.9^{\mathrm{z}}$ & $3.9 \mathrm{a}^{\mathrm{y}}$ & 4.4 & $6.4 \mathrm{a}^{\mathrm{z}}$ & $5.3 \mathrm{a}^{\mathrm{z}}$ & $5.5^{\mathrm{z}}$ & $12.5^{\mathrm{z}}$ & $3.5^{\mathrm{z}}$ & $12.6 \mathrm{a}^{\mathrm{z}}$ & 4.4 & $17.2 \mathrm{a}^{\mathrm{z}}$ \\
\hline Mulch & 8.1 & $1.9 \mathrm{~b}$ & 4.2 & $3.1 \mathrm{~b}$ & $0.5 \mathrm{~b}$ & 4.6 & 11.1 & 3.6 & $8.3 \mathrm{~b}$ & 3.2 & $12.9 \mathrm{~b}$ \\
\hline \multicolumn{12}{|l|}{ Species } \\
\hline Acer platanoides & $12.8 \mathrm{a}$ & & & 5.3 & 2.7 & $7.8 \mathrm{a}$ & $17.1 \mathrm{a}$ & $4.9 \mathrm{a}$ & -- & & $22.2 \mathrm{a}$ \\
\hline Tilia cordata & $4.3 \mathrm{~b}$ & & & 4.2 & 3.1 & $2.3 \mathrm{~b}$ & $6.5 \mathrm{~b}$ & $2.1 \mathrm{~b}$ & - & & $7.9 \mathrm{~b}$ \\
\hline Significance & \multicolumn{11}{|c|}{$P>\mathrm{F}$} \\
\hline Surface & 0.402 & & & 0.003 & 0.001 & 0.489 & 0.290 & 0.894 & 0.0 & & 0.001 \\
\hline Species & 0.001 & & & 0.215 & 0.579 & 0.001 & 0.001 & 0.001 & 0.0 & & 0.001 \\
\hline Species $\times$ surface & 0.488 & & & 0.124 & 0.260 & 0.712 & 0.290 & 0.675 & 0.0 & & 0.112 \\
\hline
\end{tabular}

${ }^{\mathrm{z}}$ Mean separation between surface treatments and species by LSD $(\mathrm{P}=0.05)$.

${ }^{\mathrm{y}}$ Mean separation between surface $\times$ species interaction by LSD $(\mathrm{P}=0.05)$. 
weekly, biweekly, or monthly irrigation schedule can be developed using daily, weekly, biweekly, or monthly $\mathrm{ET}_{\mathrm{O}}$ totals.

Surface properties also affected full sun, midday $P_{n}$ for maple and linden leaves. Because a decrease in $P_{n}$ is expected with a decrease in $g_{s}$ (Hinckley et al., 1978), reduced $P_{n}$ was anticipated for leaves over mulch compared to leaves over turf. High $\mathrm{T}_{\mathrm{L}}$ increased evaporative demand which induced stomatal closure and reduced photosynthetic rate (Hinckley et al., 1978; Turner et al., 1984) for maple and linden leaves over mulch. During the initial year of the experiment (1995), there were no differences in $P_{n}$ between maple and linden leaves (Table 3 ). However, during the second year (1996), $P_{n}$ for linden leaves was greater than $P_{n}$ for maple leaves (Table 3). Since linden trees had greater $g_{s}$ than maple trees in 1996, species differences in $P_{n}$ could be attributed to the ability of linden trees to maximize $g_{s}$ and $P_{n}$ under wellwatered conditions (Marshall and Waring, 1984). Also, Kramer and Kozlowski (1979) reported large differences in photosynthetic capacity of many tree species and attributed differences to basic metabolism or leaf anatomy.

Stem diameter increase appears to be the least sensitive growth variable to the microclimate created by the pine bark mulch surface (Table 4). Stem diameter increase generally begins later in the growing season than other growth variables and is dependent upon current photosynthetic products (Kozlowski, 1958). Late in the growing season, $\mathrm{G} \downarrow$ and maximum daily $\mathrm{T}_{\mathrm{S}}$ would decrease. Therefore, later in the growing season differences in $\mathrm{L} \uparrow$ from turf and pine bark mulch would be less, and LVPD, $g_{s}$, and $P_{n}$ (which would influence stem area growth) may be similar for leaves over each surface. Few studies have compared growth of trees in arid, urban climates with trees under more humid climatic conditions. Kjelgren and Clark (1992b, 1993) reported that 10year-old sweetgum (Liquidambar styraciflua L.) trees in an urban plaza had less shoot elongation, smaller leaves, and less stem diameter increase for two consecutive years when compared to similar sweetgum trees in a nearby park. They attributed much of the reduced growth to lower gas exchange levels caused by increased LVPD found on leaves in the urban plaza. In our study, greater LVPD for leaves over mulch also decreased gas exchange $\left(g_{s}\right.$ and $\left.P_{n}\right)$ rates throughout much of the growing season when compared to leaves over turf (Figs. 3 and 4; Tables 1 and 3 ).

Organic mulch (pine bark, pruning chips, pine needles, etc.) around landscape trees provides many benefits (Greenly and Rakow, 1995; Skroch et al., 1992). Nevertheless, research on growth of landscape trees surrounded by organic mulch has been inconsistent. Several authors report reduced apical growth for trees surrounded by organic mulch (Litzow and Pellett, 1983; Whitcomb, 1980). However, the majority of research indicates that trees surrounded by mulch will have enhanced apical (Hensley et al., 1988) and root growth (Watson, 1988; Watson and Kupkowski, 1991) when compared to trees without mulch. Comparing growth for trees surrounded by mulch from our experiment to tree growth from previous experiments should be done with caution. Experimental conditions of our research and previous research on growth of landscape trees surrounded by mulch were very different. Previous research was conducted in high humidity climates and, or with plots that did not eliminate other surfaces from the view factor of the tree. Therefore, these previous experiments did not simulate the microclimate conditions found in urban areas with arid climates.

Water stress can reduce tree growth and has been found to be a limiting factor for growth of urban trees (Kjelgren and Clark, 1992b; Whitlow et al., 1992). However, in our research trans- planted trees over turf and pine bark mulch did not show symptoms of water stress. Therefore, water stress can not explain growth differences found between trees over turf and trees over pine bark mulch. Competition between turfgrass and woody plants has also been shown to reduce growth and slow establishment of trees (Watson, 1988; Whitcomb, 1979). However, because a $0.8-\mathrm{m}^{2}$ circle of bare soil surrounded each tree grown over turf throughout the experiment, it is unlikely that competition between tree and turf roots reduced growth of trees over turf (Whitcomb, 1979). Since the rate of plant growth is dependent on the supply of photosynthate (Kramer and Kozlowski, 1979), decreased gas exchange rates for trees over mulch would explain why growth was less for trees over mulch compared to trees over turf.

Our results indicate that in an arid climate, newly transplanted, irrigated, Norway maple and littleleaf linden trees grown over pine bark mulch and turf can effectively control water loss under conditions of high energy and low humidity. Although not confirmed by direct measurement, information from this research indicates that the flux equation can reasonably estimate water loss for two tree species in an arid climate. However, caution should be used when applying $\mathrm{K}_{\mathrm{C}}$ values and equations suggested in this study to trees of different species, ages, and size, and to trees with differing microclimates and soil conditions.

Many types of nonvegetative surfaces surround urban trees (asphalt, concrete, gravel, lava rock, and organic mulch) and each surface will have unique energy balance characteristics (Kjelgren and Montague, 1996; Montague et al., 1998). In this current research, a pine bark mulch surface was used to investigate how a large, nonvegetative, urban surface would effect gas exchange and growth of urban landscape trees. Although this research is site specific and many urban trees have several surfaces in the surrounding area, information given and procedures outlined give horticulturists, plant physiologists, and landscape maintenance personnel an understanding of tree water loss and how gas exchange can be affected by surrounding surfaces. In arid climates where water supplies are often limited (Urbano, 1990), reduced soil evaporation and tree transpiration due to pine bark mulch may help conserve important irrigation water (Zajicek, 1993). However, as tree crown density increases and canopies enlarge, it would be expected that longwave radiation would be intercepted by a smaller portion of the foliage and thus reduce the effect of increased energy loading produced by a nonvegetative surface.

\section{Literature Cited}

Allen, R.G. 1993. New approaches to estimating crop evapotranspiration. Acta Hort. 335:287-294.

Allen, R.G. 1994. REF-ET: Reference evapotranspiration calculation software. Version 2.15a. Dept. Biol. and Irr. Eng., Utah State Univ., Logan.

Allen, R.G. 1996. Assessing integrity of weather data for reference evapotranspiration estimation. J. Irr. Drainage Eng. 122:97-106.

Allen, R.G., M. Smith, A. Perrier, and L.S. Pereira. 1994. An update for the definition of reference evapotranspiration. Intl. Commission Irr. Drainage Bul. 43:1-92.

American Association of Nurserymen, Inc. 1996. American standard for nursery stock. ANSI Z60.1-1996. Amer. Assn. Nurserymen, Wash., D.C.

Bacon, C.G. and S.M. Zedaker. 1986. Leaf area prediction equations for young southeastern hardwood stems. For. Sci. 32:818-821.

Bassuk, N. and T. Whitlow. 1987. Environmental stress in street trees. Acta. Hort. 195:49-57.

Baver, L.D., W.H. Gardner, and W.R. Gardner. 1972. Soil physics. 4th ed. Wiley, New York. 
Choudhury, B.J. and J.L. Monteith. 1986. Implications of stomatal response to saturation deficit for the heat balance of vegetation. Agr. For. Meteorol. 36:215-225.

Close, R.E., J.J. Kielbaso, P.V. Nguyen, and R.E. Schutzki. 1996b. Urban vs. natural sugar maple growth: II. Water relations. J. Arboricult. 22:187-192.

Close, R.E., P.V. Nguyen, and J.J. Kielbaso. 1996a. Urban vs. natural sugar maple growth: I. Stress symptoms and phenology in relation to site characteristics. J. Arboricult. 22:144-150.

Denmead, O.T. 1984. Plant physiological methods for studying evapotranspiration: Problems of telling the forest from the trees. Agr. Water. Mgt. 8:167189.

Devitt, D.A., R.L. Morris, and D.C. Bowman. 1992. Evapotranspiration, crop coefficients, and leaching fractions of irrigated desert turfgrass systems. Agron. J. 84:717-723.

Doll, D., J.K.S. Ching, and J. Kaneshiro. 1985. Parameterization of subsurface heating for soil and concrete using net radiation data. Boundary-Layer Meteorol. 32:351-372.

Farquhar, 1978. Feedforward responses of stomata to humidity. Austral. J. Plant. Physiol. 5:787-800.

Fraedrich, S.W. and D.L. Ham. 1982. Wood chip mulching around maples: Effect on tree growth and soil characteristics. J. Arboricult. 8:85-89.

Garbesi, K. 1992. Estimating water use by various landscape scenarios, p. 157172. Cooling our communities: A guidebook on tree planting and lightcolored surfacing. Lawrence Berkeley Lab.-U.S. Environ. Protection Agency, Wash., D.C.

Geiger, R. 1973. The climate near the ground. 4th ed. Oxford Univ. Press, London.

Graves, W.R., M.N. Dana, and R.J. Joly. 1989. Root-zone temperature affects water status and growth of red maple. J. Amer. Soc. Hort. Sci. 114:406-410.

Greenly, K.M. and D.A. Rakow. 1995. The effect of wood mulch type and depth on weed and tree growth and certain soil parameters. J. Arboricult. 21:225-232.

Heilman, J.L., C.L. Brittin, and J.M. Zajicek. 1989. Water use by shrubs as affected by energy exchange with building walls. Agr. For. Meteorol. 48:345-357.

Hensley, D.L., R.E. McNiel, and R. Sundheim. 1988. Management influences on growth of transplanted Magnolia grandiflora. J. Arboricult. 14:204-207.

Hinckley, T.M., R.G. Aslin, R.R. Aubuchon, C.L. Metcalf, and J.E. Roberts. 1978. Leaf conductance and photosynthesis in four species of the oakhickory forest type. For. Sci. 24:73-84.

Hoffman, G.J. J.D. Oster, and W.J. Alves. 1982. Evapotranspiration of mature orange trees under drip irrigation in an arid climate. Trans. Amer. Soc. Agr. Eng. 25:992-996.

Jones, H.G. 1992. Plants and microclimate: A quantitative approach to environmental plant physiology. 2nd ed. Cambridge Univ. Press. Cambridge, U.K.

Karlic, H. and H. Richter. 1979. Storage of detached leaves and twigs without changes in water potential. New Phytol. 83:379-384.

Kim, H.H. 1992. Urban heat island. Intl. J. Remote Sensing 13:2319-2336.

Kjelgren, R.K. and J.R. Clark. 1992a. Photosynthesis and leaf morphology of Liquidambar styraciflua $\mathrm{L}$. under variable urban radiant-energy conditions. Intl. J. Biometeorol. 36:165-171.

Kjelgren, R.K. and J.R. Clark. 1992b. Microclimates and tree growth in three urban spaces. J. Environ. Hort. 10:139-145.

Kjelgren, R.K. and J.R. Clark. 1993. Growth and water relations of Liquidambar styraciflua L. in an urban park and plaza. Trees 7:195-201.

Kjelgren, R. and T. Montague. 1996. Isolated tree water use in various urban surfaces. Proc. Intl. Conf. Evapotranspiration Irr. Scheduling. p. 250-256.

Kjelgren, R. and T. Montague. 1998. Urban tree transpiration over turf and asphalt surfaces. Atmospheric Environ. 32:35-41.

Kozlowski, T.T. 1958. Water relations and growth of trees. J. For. 56:498-502.

Kramer, P.J. and T.T. Kozlowski. 1979. Physiology of woody plants. Academic Press, New York.

Landsberg, H.E. 1979. Atmospheric changes in a growing community (the Columbia, Maryland, experience). Urban Ecol. 4:53-81.

Landsberg, J.J. and R. McMurtrie. 1984. Water use by isolated trees. Agr. Water Mgt. 8:223-242.

Levitt, D.G., J.R. Simpson, and J.L. Tipton. 1995. Water use of two landscape tree species in Tucson, Arizona. J. Amer. Soc. Hort. Sci. 120:409-416.
Litzow, M. and H. Pellett. 1983. Influence of mulch materials on growth of green ash. J. Arboricult. 9:7-11.

Marshall, J.D. and R.H. Waring. 1984. Conifers and broadleaf species: Stomatal sensitivity differs in western Oregon. Can. J. For. Res. 14:905-908.

Mastalerz, J.W. and C.S. Oliver. 1974. Microclimatic modification: Development and application in the urban environment. HortScience 9:560-563.

Miller, D.R. 1980. The two-dimensional energy budget of a forest edge with field measurements at a forest-parking lot interface. Agr. Meteorol. 22:5378.

Mitchell, C.A. 1992. Measurement of photosynthetic gas exchange in controlled environments. HortScience 27:764-767.

Montague, T., R. Kjelgren, and L. Rupp. 1998. Surface energy balance affects gas exchange of three shrub species. J. Arboricult. 24:254-262.

Monteith, J.L. 1995. A reinterpretation of stomatal responses to humidity. Plant, Cell, Environ. 18:357-364.

Monteith, J.L. and M.H. Unsworth. 1990. Principles of environmental physics. 2nd ed. Edward Arnold, London.

Mooney, H.A. and C. Chu. 1983. Stomatal responses to humidity of coastal and interior populations of a Californian shrub. Oecologia 57:148-150.

Mott, K.A. and D.F. Parkhurst. 1991. Stomatal responses to humidity in air and helox. Plant, Cell Environ. 14:509-515.

Nowak, 1996. Estimating leaf area and leaf biomass on open-grown deciduous urban trees. For. Sci. 42:504-507.

Oke, T.R. 1978. Boundary layer climates. Methuen \& Co., New York.

Peper, P.J. and E.G. McPherson. 1998. Comparison of five methods for estimating leaf area index of open-grown deciduous trees. J. Arboricult. 24:98-111.

Potts, D.F. and L.P. Herrington. 1982. Drought resistance adaptations in urban honeylocust. J. Arboricult. 8:75-80.

Sampson, D.A. and F.W. Smith. 1993. Influence of canopy architecture on light penetration in lodgepole pine (Pinus contorta var. latifolia) forests. Agr. For. Meteorol. 64:63-79.

SAS Inst.itute, Inc. 1996. The SAS system for windows. Release 6.12. SAS Inst., Cary, N.C.

Skroch, W.A., M.A. Powell, T.E. Bilderback, and P.H. Henry. 1992. Mulches: Durability, aesthetic value, weed control, and temperature. J. Environ. Hort. 10:43-45.

Tan, C.S. and R.E.C. Layne. 1981. Application of a simplified evapotranspiration model for predicting irrigation requirements of peach. HortScience 16:172-173.

Turner, N.C. 1991. Measurement and influence of environmental and plant factors on stomatal conductance in the field. Agr. Meteorol. 554:137-154.

Turner, N.C., E.D. Schulze, and T. Gollan. 1984. The responses of stomata and leaf gas exchange to vapour pressure deficits and soil water content I. Species comparisons at high soil water contents. Oecologia 63:338-342. Urbano, C.C. 1990. The great disappearing act of usable American water. Amer. Nurseryman 163(3):52-55.

Utah State Univ. 1997. Utah climate center: BLM-UCC automated network. IV. Utah State Univ., Logan.

Watson, G.W. 1988. Organic mulch and grass competition influence tree root development. J. Arboricult. 14:200-203.

Watson, G.W. and G. Kupkowski. 1991. Effects of a deep layer of mulch on the soil environment and tree root growth. J. Arboricult. 17:242-245.

Whitcomb, C.E. 1979. Factors affecting the establishment of urban trees. J. Arboricult. 5:217-219.

Whitcomb, C.E. 1980. Effects of black plastic and mulches on growth and survival of landscape plants. J. Arboricult. 6:10-12.

Whitlow, T.H. and N.L. Bassuk. 1987. Trees in difficult sites. J. Arboricult. 13:10-17.

Whitlow, T.H. and N.L. Bassuk. 1988. Ecophysiology of urban trees and their management -The North American experience. HortScience 23:542546.

Whitlow, T.H., N.L. Bassuk, and D.L. Reichert. 1992. A 3-year study of water relations of urban street trees. J. Appl. Ecol. 29:436-450.

Zajicek, J.M. 1993. Design and testing of urban landscapes for water conservation. J. Arboricult. 19:1-6.

Zajicek, J.M. and J.L. Heilman. 1991. Transpiration by crape myrtle cultivars surrounded by mulch, soil, and turfgrass. HortScience 26:1207-1210. 